\section{I $\mathbf{B}$ Anstitute of \\ YK Business Administration \\ तर Karachi \\ Leadership and Ideas for Tomorrow}

Article 12

Volume 2 Issue 1 January - June 2007

$1-1-2007$

\title{
Corruption improves efficiency: An erroneous belief
}

Naved Ahmad

Institute of Business Administration, Karachi, Pakistan.

Follow this and additional works at: https://ir.iba.edu.pk/businessreview

Part of the Inequality and Stratification Commons

(c) (i)

This work is licensed under a Creative Commons Attribution 4.0 International License.

\section{Recommended Citation}

Ahmad, N. (2007). Corruption improves efficiency: An erroneous belief. Business Review, 2(1), 168-170.

Retrieved from https://doi.org/10.54784/1990-6587.1119

This article is brought to you by iRepository for open access under the Creative Commons Attribution 4.0 License and is available at https://ir.iba.edu.pk/businessreview/vol2/iss1/12. For more information, please contact irepository@iba.edu.pk. 


\title{
DISCUSSION
}

\section{Corruption Improves Efficiency: An Erroneous Belief}

\author{
Naved Ahmad \\ Institute of Business Administration, Karachi, Pakistan.
}

\begin{abstract}
orruption plays a destructive role in the progress and development of any society ${ }^{1}$. Countries around the globe are facing the problem of corruption, albeit in different degrees. The topic of corruption received immense attention during the late 1990s when a stream of systematic empirical studies emerged to examine its causes and effects. Moreover, the debate on the beneficial and detrimental effects of corruption gets central position in the empirical literature ${ }^{2}$.
\end{abstract}

One body of theoretical literature on the effects of corruption demonstrates that corruption improves efficiency and leads to economic growth by avoiding cumbersome and lengthy government procedures. Nathaniel H Leff (1964) in his article titled "Economic Development Through Bureaucratic Corruption" published in American Behavioral Scientist, first gave this idea. He contends that if government errs in policy formulation corruption might improve welfare by reducing some of these mistakes. Others, confirming Leff's contention, argue that society with rigid, over-centralized and dishonest bureaucracy is better than the society with rigid, over-centralized and honest bureaucracy ${ }^{3}$. Corruption money is also considered as speed money for avoiding delays. To acquire public utilities in many less developed economies, one has to stand in long queues. In this situation, bribe can be used to avoid such delays ${ }^{4}$.

The argument that corruption can contribute to economic growth when government regulations are too rigid is questionable, however. With more discretionary powers, public officials often raise firm's costs by introducing unnecessary requirements in order to extort bribe. Thus bribery instead of avoiding cumbersome regulations increases administrative delays to lure more bribes. Paolo Mauro (1995), a Harvard graduate, using subjective indices of corruption assembled by Business International provides empirical evidence that corruption lowers investment and economic growth. He finds that corruption lowers private investment and economic growth even in the sub-sample of countries where bureaucratic regulations are very cumbersome. His analysis, however, does not embrace diverse effects of various forms of corruption on economic growth. He makes an implicit assumption that the effects of all types of corruption on growth are identical.

Criticizing Mauro's analysis, Andrew Wedeman (1997) of University of NebraskaLincoln analyzes the effects of corruption on growth by grouping corruption into three categories: looting, rent scraping, and dividend collecting. Looting creates capital

\footnotetext{
${ }^{1}$ See Alam (1990) for details

${ }^{2}$ See Lambsdorff (1999) for a complete review of empirical literature

${ }^{3}$ See Huntington (1968) for details

${ }^{4}$ See Kaufmann and Wei (1999) for details
} 
outflow because of insecurity, whereas rent scraping distorts the allocation of capital towards rent seeking sector. Contrary to both looting and rent scraping, dividend collecting gives incentives to corrupt officials to encourage domestic enterprise to invest and prosper in order to share their profits. The study concludes that the effect of corruption on growth will depend on the method the corrupt monies are extracted and how they are disposed.

Economists perceive that corruption always creates winners and losers; it is indeed possible that losers are not visible, albeit. The taxonomy of winners and losers in terms of their visibility in any corrupt deal provides six possible cases. First, winners are not visible but losers are. Any ill-intentioned government regulations that are intended to contrive bribes impose higher cost to the consumers who are visible. Second, both winners and losers are not visible. This is the case where corruption is collusive in nature. The above two cases best explain what Wedeman (1997) calls "Looting".

Third, winners and losers are both visible. For example corruption in the procurement of various government contracts where the officials who receive bribes and the one who is awarded the contract are winners and all the remaining bidders are losers. Fourth, winners are visible but losers are not. For example corruption in educational institutions where students are involved in cheating by paying bribes to the concerned persons or where examiners are awarding inflated grades to the students who are either their relatives, friends, or private students. In this case the students and the examiners who are involved in corruption are winners. Unfortunately this has inflicted heavy losses to those innocent students who because of this corruption are unable to either get jobs or obtain admissions of their choice on merit. They are the losers but are not visible. This type of corruption compels students to waste their energy to acquire either private tuition or find someone who can help them steal the required grades. In the jargon of economics we call it rent seeking activity. The third and fourth cases best explain what Wedeman (1997) calls "rent scraping". One can easily furnish numerous examples for the above four cases. However, it is not possible, I surmise, for any corrupt dealings that do not create winners.

The last case that is often neglected highlights a situation where corruption does not leave any victims or losers. This last case is akin to the "dividend-collecting" concept noted by Wedeman (1997). People who are involved in petty corruption in less developed countries often support Leff's argument making a case that their act does not hurt anyone. In other words, it is possible for a person to pay bribes for his or her own legal work that does not impose any cost to others. And therefore it is Pareto efficient. This type of bribery is often used to illicitly counteract other forms of corruption. For example, if one wants to get his/her passport that is legal but the system is such that one has to grease the palms of the officials to avoid unnecessary delays, many people often believe that there is no harm greasing their palms. This example can also be applied to the efficiency wage model where wages determine the efficiency of the workers. By analogy bribe can also be used as a backhander for the public officials to work efficiently. For example when people are coerced to bribe the 
officials in order to avoid delays for their legal work, it might increase overall efficiency for the following three reasons: a) people get timely and efficient services without delays; b) the officials will have the money (bribe); and c) it does not hurt others. The above arguments make Leff's contention logical.

There is a wide consensus among economists about the detrimental effects of corruption on economic growth particularly if it creates losers. However, the paucity of data on the amount of bribery primarily asked for legal work has constrained researchers to establish an empirical relationship between bribery and government efficiency. Nevertheless, corruption no matter whether it leaves victims or not is undesirable. Accepting bribes whether for doing legal or illegal work is unethical, immoral and disgusting act; and therefore should be abated. To abate corruption even if it leaves no victims, we have to edify our coming generations about the evilness of corruption and at the same time empower the victims of corruption by teaching them ethics. One important policy prescription that can be derived from this analysis is that government should not impose excessive regulations in the hope that some of these regulations can be avoided through bribery.

\section{REFERENCES}

Alam, M.S. (1990), "Some Economic Costs of Corruption in LDCs", Journal of Development Studies, 27, 1, pp. 89-97.

Huntington, S.P. (1968), "Political Order in Changing Societies", New Haven: Yale University. Press.

Lambsdorff, J.G. (1999), “Corruption in Empirical Research - A Review”, Working Paper, http://www.transparency.org/working_papers/lambsdorff/lambsdorff_eresearch.html

Leff, N. (1964), "Economic Development through Bureaucratic Corruption”, American Behavioral Scientist, 8, pp. 8-14.

Mauro, P. (1995), "Corruption and Growth", Quarterly Journal of Economics, 110, pp. 681-712.

Mauro, P. (1997), “The Effects of Corruption on Growth, Investment, and Government Expenditure: A Cross Country Analysis", Kimberly Ann Elliott, eds., Corruption and the Global Economy (Institute of International Economics, Washington, D.C., June 1997), pp. 83-107.

Wedeman, A. (1997), "Looters, Rent-scrapers, and Dividend-collectors: Corruption and Growth in Zaire, South Korea, and the Philippines", The Journal of Developing Areas 31, 4, pp. 457-478.

Kaufmann, D., and Shang-Jin, W. (1999), "Does Grease Money Speed Up the Wheels of Commerce?" National Bureau of Economic Research Working Paper 7093, Cambridge, MA.

It is one thing to tell the truth even when it damages your friends. It's another to tell untruths in order not to offend your enemies.

Clifford D. May, President

Foundation for the Defense of Democracies 